\title{
PENGARUH SIKAP GURU \\ TERHADAP PENGEMBANGAN KARAKTER (PEDULI SOSIAL) SISWA DI MI MADINATUNNAJAH KOTA CIREBON
}

\author{
Akhmad Busyaeri*, Mumuh Muharom \\ *Dosen Jurusan PGMI FITK IAIN Syekh Nurjati Cirebon
}

\begin{abstract}
ABSTRAK
Sikap merupakan sesuatu yang dipelajari dan sikap menentukan bagaimana individu bereaksi terhadap situasi serta menentukan apa yang dicari individu dalam kehidupannya. Sikap mengandung tiga komponen, yaitu komponen kognitif, komponen afektif dan tingkah laku. Sikap selalu berkenaan dengan suatu objek dan sikap terhadap objek ini disertai dengan perasaan positif dan negatif. Sikap dari seorang guru adalah salah satu faktor yang menentukan bagi perkembangan jiwa anak didik selanjutnya. Karena sikap seorang guru tidak hanya dilihat dalam waktu mengajar saja, tetapi juga dilihat tingkah lakunya dalam kehidupan sehari-hari oleh anak didiknya.

Penelitian ini menggunakan metode pendekatan kuantitatif, untuk pengumpulan data dilaksanakan dengan teknik penyebaran angket dan studi dokumentasi. Pengambilan sampel pada penelitian ini dilakukan dengan cara populasi sampel dan dipilih kelas $\mathrm{V}$ yang berjumlah 24 siswa. yang dijadikan sampel pada penelitian ini adalah siswa kelas V. Dan untuk menganalisis data, penulis menggunakan analisis regresi dengan bantuan program SPSS 17.0 for windows.

Pengaruh sikap guru di MI Madinatunajah kota Cirebon berada dalam kategori sedang. Hal ini dapat diketahui bahwa hasil angket pengaruh sikap guru sebesar 42,08 berada pada interval 36-55 (sedang), Dan pengembangan karaktr (peduli social) kelas V di MI Madinataunnajah mencapai 43,42 sedangkan median (nilai tengahnya) adalah 44,00, serta modus (nilai yang sering muncul) juga diperoleh dengan nilai 44. Dari hasil analisis menunjukan Koefisien Korelasi sebesar 0,511 dan Koefisien Determinasi sebesar 26,11\%. Dan nilai $t_{\text {hitung }}$ sebesar 2,787. Karena thitung > tabel yakni 2,787 > 1,717. Maka hipotesis diterima.
\end{abstract}

\section{A. Pendahuluan}

Tujuan pendidikan yang terdapat dalam batang tubuh pemukaan undang-undang dasar 1945 yakni "mencerdaskan kehidupan bangsa". Kemudian diperinci dan diperjelas dalam Undang - Undang No. 20 Tahun 2003 pasal 3 menjelaskan bahwa pendidikan nasional berfungsi 
mengembangkan kemampuan dan membentuk watak serta peradaban bangsa yang bermartabat dalam rangka mencerdaskan kehidupan bangsa. Untuk itu, pendidikan nasional bertujuan untuk mengembangkan potensi peserta didik agar menjadi manusia yang beriman dan bertakwa kepada Tuhan yang maha esa, berakhlak mulia, sehat, berilmu, cakap, kreatif, mandiri, dan menjadi warga negara yang demokratis serta bertanggungjawab (Mulyasa, 2013: 20).

Tujuan pendidikan nasional sebagai rumusan arah pendidikan Indonesia yang harus dimiliki oleh setiap warga Indonesia melalui jalur pendidikan. Dalam tujuan pendidikan nasional memuat berbagai nilai kemanusiaan, dimana nilai-nilai kemanusiaan ini harus dimiliki oleh bangsa Indonesia, agar cita-cita luhur bangsa Indonesia untuk menjadikan bangsa yang cerdas dan bermartabat dapat terwujud. Untuk mewujudkan tujuan pendidikan nasional tersebut berbagai upaya perbaharuan sistem pendidikan telah dilakukan guna untuk meningkatkan kualitas pendidikan nasional yang disesuaikan dengan perubahan zaman dan arah tujuan pendidikan nasional.

Dalam tujuan pendidikan telah diterangkan bahwa salah satu tujuan pendidikan yaitu memuat nilai-nilai kemanusiaan yang harus dimiliki oleh bangsa indonesia. Salah satu nilai-nilai tersebut yaitu sikap sosial. La Pierre dalam Azwar (2003) mengidentifikasikan peduli sosial sebagai suatu pola perilaku, tendensi atau kesiapan antisipatif, predisposisi untuk menyesuaikan diri dalam situasi sosial.

Peduli sosial terbentuk dari adanya interaksi sosial yang dialami oleh individu. Interaksi sosial mengandung arti lebih dari pada sekedar adanya kontak sosial dan hubungan antar individu sebagai anggota kelompok sosial. Dalam interaksi sosial, terjadi hubungan saling mempengaruhi diantara individu yang satu dengan yang lain, terjadi hubungan timbal balik yang turut mempengaruhi pola perilaku masing-masing individu sebagai anggota masyarakat. 
Dalam interaksi sosialnya, individu bereaksi membentuk pola sikap tertentu terhadap berbagai objek psikologis yang dihadapinya. Diantara berbagai factor yang mempengaruhi pembentukan sikap adalah pengalaman pribadi, kebudayaan, orang lain yang dianggap penting, media massa, institusi atau lembaga pendidikan dan lembaga agama, serta factor emosi dalam diri individu.

Cort Land salah seorang pakar psikologi perkembangan anak di university New York dalam Nini S (2011:42) menjelaskan bahwa peradaban manusia telah mengalami kemunduran sejalan dengan kemunduran karakter generasi muda kita. Hal ini tentunya menjadi tugas wajib bagi kita semua untuk segera mempebaiki sebelum bangsa ini benar-benar hancur.

Pendidikan merupakan fondasi bangsa, melaui lembaga pendidikan sumber daya manusia Indonesia akan lebih berkualitas dan bermartabat. Hal ini tidak terlepas dari peran semua komponen dalam lembaga pendidikan. Dimana yang berperan dalam lembaga pendidikan meliputi kepala sekolah, wakil kepala sekolah, staf sekolah, dan pendidik atau guru.

Pendidikan pada hakekatnya merupakan suatu peristiwa yang mempunyai aspek normatif, yang artinya bahwa dalam peristiwa pendidikan, pendidik dan anak didik berlangsung pada ukuran norma atau nilai-nilai yang diyakini sebagai sesuatu yang baik. Pendidikan sangat mempengaruhi kehidupan manusia, karena dengan mencapai pendidikan yang tinggi manusia akan dihormati, disegani dan dijunjung tinggi martabatnya dimasyarakat. Oleh kerena itu betapa pentingnya guru bersikap baik dalam kegiatan belajarmengajar terhadap anak didiknya.

Guru merupakan personalia penting dalam pendidikan, selain itu guru merupakan seorang yang hubungannya paling dekat dengan peserta didik. sebagian besar interaksi yang terjadi di sekolah, adalah interakasi guru dengan peserta didik. Baik melaui proses pembelajaran akademik kulikuler, ekstra kulikuler. Di sekolah guru merupakan figur yang diharapkan mampu 
mendidik anak yang berkarakter, berbudaya dan bermoral (Zubaedi, 2013: 164).

Guru menjadi fokus utama untuk mewujudkan keberhasilan pendidikan sesuai dengan tujuan pendidikan nasional. Guru juga sebagai panutan siswa dan masyarakat, guru sebagai produser yang membuat dan menyusun skenario pembelajaran, karena guru sebagai pemegang estapet terakhir dalam pendidikan untuk menjadikan siswanya menjadi seorang yang berintelektual dan berkarakter. Guru adalah orang yang sangat berpengaruh dalam proses belajar mengajar. Seorang guru harus benar-benar membawa siswanya kepada tujuan yang ingin dicapai.

Dalam Standar Nasional Pendidikan, Pasal 28 ayat 3 butir d, dikemukakan bahwa yang dimaksud dengan kompetensi sosial adalah kemampuan guru sebagai bagian dari masyarakat untuk berkomunikasi dan bergaul secara efektif dengan peserta didik, sesama pendidik, tenaga kependidikan, orang tua/wali peserta didik, dan masyarakat sekitar.

Keberhasilan seorang guru dalam mendidik siswanya ditentukan apabila guru tersebut telah mewujudkan konsep Ki Hajar Dewantara.Konsep pendidikan Ki Hajar Dewantara, yaitu, Ing ngarso sung tulodo (di depan dapat memberi teladan), ing madya mangun karso (di tengah dapat memberi motivasi), dan tut wuri handayani (di belakang dapat mengawasi) (Aryani, 2010: 9).

Sebagaimana yang tercantum dalam Undang Undang Peraturan Pemerintah No. 19 Tahun 2005 tentang Standar Nasional Pendidikan bahwa guru di Indonesia diharapkan punya empat kompetensi dalam menjalankan profesinya, yaitu kompetensi pedagogi, kompetensi kepribadian, kompetensi profesional dan kompetensi sosial (Chatib, 2010:28).

Tugas seorang guru tidak hanya di sekolah akan tetapi di lingkungan masyarakat ia juga harus menjadi panutan masyarakat. Guru harus menjadi seorang dewasa yang berbeda dengan orang dewasa lainnya. Artinya ia harus 
senantiasa berprilaku yang baik di lingkungan sekolah dan di lingkungan masyarakat,karena segala tindakannya senantiasa akan ditiru oleh siswa.

Guru sebagai pengganti peran orang tua di sekolah perlu memiliki kesadaran, pemahaman, kepedulian, dan komitmen untuk membimbing peserta didik menjadi manusia-manusia shaleh yang bertakwa. Mengingat bahwa pendidikan karakter menekankan pada aspek sikap, nilai, dan watak peserta didik, maka dalam pembentukannya harus dimulai dari gurunya. (E.Mulyasa, 2013:31). Dalam hal ini, bagaimana setiap lembaga pendidikan baik formal maupun non formal dapat mewujudkan guru yang dapat digugu dan ditiru. Karena akhir-akhir ini banyak guru yang kehilangan semangat pengabdiannya.

Peranan guru di sekolah ditentukan oleh kedudukannya sebagai orang dewasa, sebagai pengajar dan pendidik dan sebagai pegawai, yang paling utama ialah kedudukanya sebagai pengajar dan pendidik, yakni sebagai guru. Berdasarkan kedudukannya sebagai soerang guru ia harus menunjukan kelakuan yang layak bagi guru menurut harapan masyarakat. apa yang dituntut dari guru dalam aspek etis, intelektual dan sosial lebih tinggi dari pada yang ditunntut dari orang dewasa lainnya. Guru sebagai pendidik dan pembina generasi muda harus menjadi teladan, di dalam maupun di luar sekolah (Nasution, 2010: 91).

Pembentukan karakter menjadi salah satu tujuan pendidikan nasional. Pasal 1 undang-undang sistem pendidikan nasional nomor 20 tahun 2003 menyebutkan di antara tujuan pendidikan nasional adalah mengembangkan potensi peserta didik untuk mempunyai kecerdasan, kepribadian, dan akhlak mulian.

Amanah undang-undang sistem pendidikan nasional nomor 20 tahun 2003 ini bermaksud agar pendidikan tidak hanya membentuk manusia indonesia yang cerdas, tetapi juga berkepribadian atau berkarakter sehingga 
nantinya akan lahir generasi bangsa yang tumbuh berkembang dengan karakter yang bernapas nilai-nilai luhur bangsa serta agama.

Presiden susilo bambang yudhoyono ketika memberikan kata sambutan pada puncak peringata hari pendidikan nasional (Hardiknas) tahun 2010 di istana negara, jakarta, selasa, 11 mei 2010 yang bertemakan, "pendidikan karakter untuk membangun peradaban bangsa," beliau mengemukakan lima isu penting dalam dunia pendidikan. Pertama, hubugan pendidikan dengan pembentukan watak atau yang dikenal dengan character building. Kedua, kaitan pendidikan dengan kesiapan dalam menjalani kehidupan setelah seseorang selesai mengikuti pendidikan. Ketiga, kaitan pendidikan dengan lapangan pekerjaan. Keempat, bagaimana membangun masyarakat berpengetahuan atau knowledge society yang dimulai dari meningkatkan basis pengetahuan masyarakat. Kelima, bagaimana membangun budaya inovasi (Kurniawan, 2013: 68).

Menteri pendidikan nasional juga dalam sambutannya pada peringatan hari pendidikan nasional tanggal 2 mei 2010 juga menekankan bahwa pembangunan karakter dan pendidikan karakter merupakan suatu keharusan karena pendidikan tidak hanya menjadikan peserta didik menjadi cerdas tetapi juga mempunyai budi pekerti atau perilaku yang baik (Kurniawan, 2013: 73).

Dari beberapa penjelasan diatas dapat di simpulkan bahwa menunjukan komitmen pemerintah terhadap pengembangan dan kesuksesan pendidikan karakter cukup besar sehingga patut diapresiasi dan didukung oleh semua pihak. Pendidikan karakter memerlukan pembiasaan untuk berbuat baik, pembiasaan untuk berlaku jujur, malu berbuat curang, dan lain-lain. Karakter tidak terbentuk secara instan, tetapi harus dilatih secara serius dan proporsionalagar mencapai bentuk dan kekuatan yang ideal. Agar bisa efektif, pendidikan karakter sebaiknya dikembangkan melalui pendekatan terpadu dan menyeluruh. Efektivitas pendidikan karakter tidak selalu harus dengan menembah program sendiri, tetapi bisa melalui transformasi budaya dan 
kehidupan di lingkungan sekolah. Melalui pendidikan karakter, semua berkomitmen untuk menumbuhkembagkan peserta didik menjadi pribadi utuh yang menginternalisasi kebijakan (tahu dan mau) dan terbiasa mewujudkan kebijakan itu dalam kehidupan sehari-hari.

Kepedulian sosial adalah sebuah tindakan, bukan hanya sebatas pemikiran atau perasaan. Tindakan peduli sosial tidak hanya tahu sesuatu yang yang salah dan benar, tapi ada kemauan melakukan gerakan membantu orang lain. Dengan memiliki jiwa sosial yang tinggi, anak didik akan lebih mudah bersosialisasi serta akan lebih dihargai. Pembentukan jiwa sosial anak didik dapat dilakukan dengan mengajarkan dan menanamkan nilai-nilai kepedulian sosial melalui kegiatan yang bersifat sosial, melakukan aksi sosial, dan menyediakan fasilitas untuk menyumbang (Kurniawan, 2013: 157-158).

Berdasarkan pengamatan awal yang dilakukan di MI Madinatunnajah Kota Cirebon, diketahui bahwa guru kelas V dalam kehidupan sehari-hari di lingkungan sekolah bersikap ramah, santun, disiplin, solidaritas dan peduli dterhadap rekan-rekan sejabat. Guru tersebut tidak hanya bersikap baik kepada rekan-rekan sejabat saja, bahkan kepada siswa dan kepada peneliti

juga guru selau bersikap terbuka dan peduli. Namun, masih saja ada siswa yang kurang memiliki sikap peduli terhadap teman-temannya. Misalnya, siswa tidak mau membantu siswa yang membutuhkan bantuan, siswa kurang memiliki rasa empati terhadap teman yang dalam keadaan sakit atau dalam kesulitan.

\section{B. Gambaran sikap Guru di MI Madinatunnajah Kota Cirebon}

Sikap merupakan sesuatu yang dipelajari dan sikap menentukan bagaimana individu bereaksi terhadap situasi serta menentukan apa yang dicari individu dalam kehidupannya. Sikap mengandung tiga komponen, yaitu komponen kognitif, komponen afektif dan tingkah laku. Sikap selalu 
berkenaan dengan suatu objek dan sikap terhadap objek ini disertai dengan perasaan positif dan negatif. Sikap dari seorang guru adalah salah satu faktor yang menentukan bagi perkembangan jiwa anak didik selanjutnya. Karena sikap seorang guru tidak hanya dilihat dalam waktu mengajar saja, tetapi juga dilihat tingkah lakunya dalam kehidupan sehari-hari oleh anak didiknya.

Guru adalah orang dewasa yang secara professional bertugas untuk melaksanakan proses pendidikan secara keseluruhan terhadap peserta didik serta untuk membina akhlak atau karakter peserta didik agar menjadi manusia yang berpengetahuan serta berkarakter. Guru juga merupakan orang yang sangat berpengaruh dalam proses belajar mengajar. Seorang guru harus benarbenar membawa siswanya kepada tujuan yang ingin dicapai serta mempunyai pandangan yang luas dan berwibawa atau kewibawaan.

Berdasarkan penelitian yang dilakukan oleh penulis dapat diketahui bahwa nilai rata-rata sikap guru sebesar 42.08 berada pada interval 36-55 hal ini menunjukan bahwa sikap guru di MI Madinatunnajah kota Cirebon berada dalam kategori sedang, yaitu seperti yang terlihat pada skor angket terendah yakni item no 5, yang merupakan komponen dari sikap guru terhadap proses belajar siswa. Dimana jika dilihat dari sudut pandang kajian teori pada BAB II, item pernyataan berkaitan dengan guru memiliki wawasan yang luas.

Dengan mengkorelasikan teori dengan hasil penelitian yang terdapat dalam analisis deskriptif, dalam realitanya memang menunjukan bahwa aspek sikap guru terhadap pengembangan karakter (peduli sosial) itu sendiri memang sedang. Sebagai contoh dalam pengamatan penulis ada beberapa hal yang menunjukan rendahnya keterkaitan tersebut, seperti $41,7 \%$ guru memiliki wawasan yang luas.

Hal ini terbukti dengan teorinya Suyanto, (2013, 41-43) bahwa guru harus memiliki empat kompetensi yaitu kompetensi pegagogis, kompetensi profesioanal, kompetensi kepribadian, dan kompetensi sosial. 
Terdapat empat kompetensi guru dengan elemen dan indikatornya yaitu: Pertama, Kompetensi pedagogis, kompetensi ini mencakup kemampuan yang berkenaan dengan pemahaman terhadap peserta didik, perancang dan pelaksanaan pembelajaran, evaluasi hasil belajar, dan pengembangan peserta didik untuk megaktualisasikan berbagai potensi yang dimilikinya. Kedua, Kompetensi professional, kompetensi ini menyangkut kemampuan yang berhubungan dengan penguasaan materi pembelajaran bidang studi secara luas dan mendalam yang meliputi penguasaan substansi isi materi kurikulum mata pelajaran di sekolah dan substansi keilmuan yang menaungi materi kurikulum, serta menambah wawasan keilmuan sebagai guru. Ketiga, Kompetensi sosial. merupakan kemampuan pendidik sebagai bagian dari masyarakat untuk berkomunikasi dan bergaul secara efektif dengan peserta didik, sesame pendidik, tenaga pendidikan, orang tua peserta didik, dan masyarakat sekitar. Keempat, Kompetensi kepribadian. kompetensi ini menunjuk pada kemampuan personal yang mencerminkan kepribadian mantap, stabil, dewasa, arif, dan berwibawa, menjadi teladan bagi peserta didik, dan berakhlak mulia.

Jadi penulis dapat menarik kesimpulan bahwa guru harus memiliki pengatahun yang luas. Bukan pengetahuan ilmu semata, melainkan harus memiliki jika mengerti anak dan pemahaman terhadap karakter peserta didiknya. Guru yang memiliki kesemua indiator itu maka secara tidak langsung guru sudah menajdi guru yang propesional dan berwawasan luas. Selayaknya guru harus bisa mencerminkan sikap dan tingkah laku yang baik untuk ditiru oleh siswanya.

\section{Gambaran pengembangan karakter (peduli sosial) di MI Madinatunnajah Kota Cirebon}

Karakter adalah cara berpikir dan berperilaku yang menjadi ciri khas tiap individu untuk hidup dan bekerja sama, baik dalam lingkup keluarga, masyarakat, bangsa, dan negara. Individu yang berkarakter baik adalah 
individu yang bisa membuat keputusan dan siap mempertanggung jawabkan tiap akibat dari keputusan yang ia buat.

Secara garis besar bahwa yang dimaksud dengan karakter yaitu perilaku yang ditunjukan oleh individu di lingkungan sosialnya yang sesuai dengan nilai dan norma yang telah ditetapkan di lingkungannya. Artinya karakter ini adalah perilaku yang baik atau positif yang ditunjukan oleh individu.

Menurut Anwas,( 2010:137) Sejalan dengan tumbuh kembangnya anak, pada lingkungan sekolah, penanaman pendidikan karakter lebih kompleks. Anak-anak dituntut belajar berperilaku dalam menghayati, mengamalkan nilai dan norma, dan akhlak mulia. Pembinaan karakter yang mudah dilakukan ketika anak-anak masih duduk di bangku sekolah dasar. Itulah sebabnya pemerintah memprioritaskan pendidikan karakter di sekolah dasar, bukan berarti jenjang yang lainnya tidak mendapat perhatian, namun porsinya saja yang berbeda. Pendidikan karakter yang diterapkan di sekolah tidak diajarkan dalam mata pelajaran khusus. Namun dilaksanakan melalui keseharian pembelajaran yang sudah berjalan disekolah. Penanaman dan pembiasaan dalam menanamkan nilai-nilai luhur di lingkungan sekolah harus harus terintegrasi dalam proses pembelajaran pada setiap mata pelajaran. Pembiasaan dan penciptaan lingkungan yang kondusif serta menjadi figur bagi peserta didik adalah pekerjaan yang tidak mudah.

Berdasarkan penelitian yang dilakukan oleh penulis dapat diketahui bahwa nilai rata-rata angket siswa yang diikuti oleh 24 responden di MI Madinatunnjah kota Cirebon adalah 43,42.

Jika dikorelasikan antara teori dengan hasil penelitian yang terdapat dalam analisa deskriptif, dalam realitanya menunjukan bahwa aspek sikap guru terhadap pengembangan karakter (peduli sosial) di MI Madinatunnajah Kota Cirebon masih rendah, sebagai contoh dalam pengamatan penulis 
dibuktikan rendahnya skor angket item 10 yaitu sebagian siswa masih memilih-milih teman bermain.

Hal ini terbukti dari teorinya Zulkifli (2006: 45) Interaksi di kalangan manusia; interaksi adalah komunikasi dengan manusia lain, hubungan yang menimbulkan perasaan sosial yaitu perasaan yang mengikatkan individu dengan sesama manusia, perasaan hidup bermasyarakat seperti saling tolong menolong, saling memberi dan menerima, simpati dan antipasti, rasa setia kawan, dan sebagainya.

Penulis menyimpulkan bahwa, dengan rendahnya hasil angket siswa mengenai pengembangan karakter (peduli sosial). Masih banyak siswa yang memilih-milih teman bermain. Sebaikanya seorang guru harus memberikan arahan kepada anak didiknya bahwa kita semua sama, tidak ada yang harus dibeda-bedakan. Baik buruknya seorang teman tetap harus kita dekati, dan guru semestinya memberikan contoh kepada siswa untuk mendekati anak yang terlihat jarang bergaul.

Karena islam telah mengajarkan dan mengatur bagaimana adab-adab seta batasan-batasan dalam pergaulan, pergaulan sangat memperngruhi kehidupan seseorang . dampak buruk akan menimpa seseorang akibat bergaul dengan teman-teman yang jelek, sebaliknya manfaat yang besar akan didapatkan dengan bergaul dengan orang-orang yang baik. Namun walau demikian kita tetap harus menjalin silaturahmi dengan teman siapapun itu, ketika teman kita bersikap buruk maka kita selaku teman dan guru yang baik wajibmenasehati dan mengaak ke perbuatan dan tingkah laku yang baik.

\section{Gambaran pengaruh sikap guru terhadap pengembangan karakter (peduli sosial) siswa kelas V di MI Madnatunnajah kota Cirebon}

Berdasarkan perhitungan koefisien regresi didapat nilai sikap guru (variable X) sebesar 42,08 . hal ini berarti pengembangan (peduli sosial) 
dipengaruhin oleh sikap guru sebesar 43,42 \% sisanya dipengaruhi oleh faktor lain yaitu bisa faktor keluarga, faktor lingkungan, maupun faktor sekolah.

Dengan diterima hipotesis ini, dapat diketahui bahwa untuk meningkatkan pengembangan karakter (peduli sosial) siswa kelas V di MI Madinatunnajah kota Cirebon dapat dilakukan dengan cara meningkatkan sikap guru sebesar 42,08\% dan sisanya dipengaruhi oleh faktor lain.

Seperti halnya menurut salahudin (2013:91) yang penulis ungkapkan di BAB II, bahwa faktor dari lingkungan sekolah yang mempengaruhi belajar antara lain: kondisi ruangan, jumlah siswa, kondisi guru, kondisi peralatan belajar mengajar, alat peraga, cara guru mengajarnya dan manajemennya. Terhadap hal ini salahudin (2013:91), mengemukakan sebagai berikut:

Pengaruh faktor lingkungan sekolah seperti guru, cara mengajarnya, alat yang digunakannya, lingkungan/susunan belajarnya, kesempatan yang tersedia dan pengembangan sosialnya. Dari keterangan ini dapat diketahui bahwa penguasaan materi seorang guru berpengaruh terhadap proses pengembangan karakter (peduli sosial).

Guru selalu ingat betapa pentingnya memberikan alasan-alasan kepada siswa mengapa siswa itu harus belajar dengan sungguh-sungguh dan berusaha untuk berprestasi dengan sebaik-baiknya. Guru juga sering menjelaskan kepada siswanya tentang apa yang diharapkan dari mereka selama dan sesudah proses belajar berlangsung. Seorang guru juga mengusahakan agar siswa-siswanya mengetahui tentang jangka pendek dan jangka panjang dari pelajaran yang sedang diikutinya dengan adanya memberikan pengetahuan secara umum dari penerapan pelajaran tersebut.

Di MI Madinatunajah juga tersedia fasilitas yang memadai misalnya tentang fasilitas perpustakaan, media pembelajaran, alat peraga yang memadai dan lab computer, dan guru yang selalu mengarahkan dan membimbing siswanya. Namun fasilitas tersebut belum memadai dari 
adanya peduli sosial yang merupakan tujuan utama dari proses pengembangan karakter, karena keberhasilan peduli sosial merupakan tujuan utama dari pembentukan karakter.

Setelah penulis melakukan penelitian bahwa dari pihak guru dan sekolah sudah memberikan fasilitas yang terbaik dan guru memberikan arahan dan semangat untuk siswanya. Namun masih saja ada anak yang masih memilih-milih teman dan ada siswa yang kurang bersikap adil terhadap temannya, baik dilihat dari kondisi sosial ekonominya, status sosialnya maupun kondisi intelektualnya.

Pada akhirnya penulis menyimpulkan pengaruh sikap guru terhadap pengembangan karakter (peduli sosial) siswa yang paling banyak menjawab adalah sebagi berikut: kuesioner item no 1 sebanyak 21 orang $78 \%$ yang termasuk pada kategori sangat setuju guru menguasai materi belajar.

Berdasarkan hasil penelitian bahwa hal ini dapat terbukti dengan teori yang disebutkan oleh Djamarah, (2010: 34) Guru adalah orang yang bertanggungjawab mencerdaskan kehidupan anak didik. pribadi susila yang cakap adalah sangat diharapkan oleh anak didik. Guru dengan penuh dedikasi dan loyalitas berusaha membimbing dan membina anak didik agar di masa mendatang menjadi orang yang berguna bagi nusa dan bangsa.

Dari beberapa penjelasan tersebut diatas terkait dengan hakikat guru, secara garis besar bahwa yang dimaksud dengan guru adalah orang dewasa yang secara professional bertugas untuk melaksanakan proses pendidikan secara keseluruhan terhadap peserta didik serta untuk membina akhlak atau karakter peserta didik agar menjadi manusia yang berpengetahuan serta berkarakter. Guru juga merupakan orang yang sangat berpengaruh dalam proses belajar mengajar. Seorang guru harus benar-benar membawa siswanya kepada tujuan yang ingin dicapai serta mempunyai pandangan yang luas dan berwibawa atau kewibawaan. 
Mengacu pada Undang-Undang Peraturan Pemerintah No. 19 Tahun 2005 tentang standar pendidikan bahwa guru harus memiliki empat kompetensi yaitu kompetensi pegagogis, kompetensi profesioanal, kompetensi kepribadian, dan kompetensi sosial.

Hasil penelitian diatas membuktikan kebenaran teori yang menyatakan bahwa sikap peduli sosial siswa kelas V di MI Madinatunnnjah dipengaruhi oleh sikap guru.

Menurut Salahudin (2013: 112) peduli sosial adalah sikap dan tindakan yang selalu ingin memberi bantuan pada orang lain dan masyarakat yang membutuhkan.

Sikap peduli sosial secara umum adalah hubungan antara manusia dengan manusia yang lain, saling ketergantungan dengan manusia lain dalam berbagai kehidupan masyarakat.

Pembentukan sikap sosial anak mengandung tiga komponen, yaitu: kognitif (konseptual), afektif (emosional), konatif (perilaku atau action component). Komponen kognitif yaitu komponen yang berkaitan dengan pengetahuan, pandangan, keyakinan, yaitu hal-hal yang berkaitan dengan bagaimana orang mempersepsi objek sikap. Komponen afektif yaitu yang berhubungan rasa senang atau tidak senang terhadap objek sikap. Komponen konatif yaitu komponen yang berkaitan dengan kecenderungan untuk berperilaku terhadap objek sikap. Komponen ini menunjukkan intensitas sikap, yaitu menunjukkan besar kecilnya kecenderungan bertindak atau berperilaku seseorang terhadap objek.

Jadi penulis dapat menyimpulkan guru ketika berada didalam kelas diibaratkan sebagai seorang pedagang yang sedang menjual barang dagangannya. Calon pembelinya adalah siswa-siswinya. barang dagangannya adalah ilmu pengetahuan yang dimilikinya, layaknya seorang pedagang yang akan melakukan promosi apa saja untuk membuat dagangannya laku terjual, 
gurupun juga demikian . guru akan melakukan apa saja untuk membuat siswa siswinya tertarik pada materi yang diajarkan.

Jadi guru harus memiliki kemampuan yang baik dan menguasai materi. Dan guru harus mengecek materi yang telah disampaikan kepada siswanya.bukan hanya materi, tetapi guru juga harus mempunyai kemampuan untuk memahami karakter anak, sebagai modal utama seorang guru untuk pembentukan karakter anak (peduli sosial) yang baik.

\section{E. Penutup}

Pengaruh sikap guru terhadap siswa kelas V di MI Madinatunnajah kota Cirebon mencapai pada angka 42,08 berada pada interval 36-55 hal ini menunjukan bahwa sikap guru di MI Madinatunnajah berada dalam kategori sedang.

Pengembangan karakter (peduli sosial) di Madrasah Ibtidaiyah Madinatunnajah kota Cirebon yang dilihat dari skor angket masing-masing siswa dan dapat dianalisis dengan menggunakan rumus Mean, Median, dan Modus. Dapat diketahui bahwa mean dari pengambangan karakter (peduli sosial) siswa mencapai 43,42 sedangkan median (nilai tengahnya) adalah 44,00, serta modus (nilai yang sering muncul) juga diperoleh dengan nilai 44.

Sikap guru berpengaruh positif terhadap pengembangan karakter (peduli sosail) siswa kelas V di MI Madinatunnajah kota Cirebon sebesar $26,11 \%$, sisanya $73,89 \%$ dipengaruhi oleh faktor lain yaitu lingkungan keluarga, lingkungan bermain, dan lingkungan sekolah. 


\section{DAFTAR PUSTAKA}

Ahmadi, Abu.(2007). Psikologi Sosial. Jakarta: Rineka Cipta

Aqib, Zainal. (2015). Pendidikan Karakter di Sekolah Membangun Karakter dan Kepribadian Anak. Bandung: Ryama Widya

Arikunto, Suharsimi,. (2013). Dasar-dasar Evaluasi Pendidikan Edisi 2. Jakarta:Bumi Aksara

Arismantoro. 2008. Tinjauan Berbagai Aspek Character Building. Yogyakarta: Tiara Wacana

Chatib, Munif. (2009). Sekolahnya Manusia. Bandung: PT. Mizan Pustaka.

Depdiknas. 2010. Rencana Aksi Nasional Pendidikan Karakter. Jakarta.

Dirganuarsa Singgih. 2008. Pengantar Psikologi. Jakarta: Mutiara

Djamarah, Bahri, Syaiful. (2010). Guru dan Anak Didik dalam Interaksi Edukasi. Jakarta: Rineka Cipta

E. Mulyasa. (2013). Pengembangan dan Implementasi Kurikulum 2013. Bandung: PT. Remaja Rosda Karya

Hasan, Said Hamid dkk. (2010). Pengembangan Pendidikan Budaya dan Karakter Bangsa. Jakarta : Puskur Balitbang Kemendiknas

Ine Kusuma Aryani, dkk. (2010). Pendidikan Kewarganegaraan Berbasis Nilai. Bogor: Ghalia Indonesia.

Iskandar. (2008). Metodologi Penelitian Pendidikan Sosial (Kuantitatif dan Kualitatif). Jakarta : Gaung Persada Press Jakarta.

Kesuma, Dharma, Pendidikan Karakter: Kajian Teori dan Praktek di Sekolah. Bandung: PT Remaja Rosdakarya, 2011.

Lickona, Thomas. Ed.3. cet. 3. (2013). Educating for Caracter (Mendidik untuk Membentuk Karakter). Terj. Juma Abdu Wamaungo. Jakarta : Bumi Aksara

Majid, Abdul. (2012). Perencanaan Pembelajaran (Mengembangkan Standar Kompetensi Guru). Bandung: PT. Remaja Rosdakarya Offset

Manfaat, Budi. (2013). Pengantar Metode Statistika. Cirebon: Eduvision publishing. 
Mujtahid, 2011. Pengembangan Profesi Guru. Malang: UIN Maliki Press

Mulyasa, E. 2005. Menjadi Guru Profesional (menciptakan pembelajaran kreatif dan menyenangkan). Bandung: PT Remaja Rosdakarya

Mulyasa, H.E. Prof. Dr., (2013). Manajemen Pendidikan Karakter. Jakarta: Bumi Aksara.

Mursidin. 2011. Moral Sumber Pendidikan (Sebuah Formula Pendidikan Budi Pekerti di Sekolah/Madrasah). Bogor: Galia Indonesia

S. Nasution. (2010). Sosiologi Pendidikan. Jakarta: PT Bumi Aksara.

Salahudin, Anas, dkk. 2013. Pendidikan Karakter (Pendidikan Berbasisi Agama dan Budaya Bangsa). Bandung: Pustaka Setia

Saptono, 2011. Dimensi-dimensi Pendidikan Karakter (wawasan, strategi, dan langkah praktis). Jakarta : Erlangga

Sholeh, Ni'am, Ashrorun. (2006). Reorientasi Pendidikan Islam Mengurai Relevansi Konsep Al-Ghazali dalam Konteks Kekinian. Jakarta: elSAS

Sjarkawi. 2008. Pembentukan Kepribadian Anak (Peran Moral Intelektual, Emosional, dan Sosial Sebagai Wujud Integritas Membangun Jati Diri). Jakarta : PT Bumi Aksara

Sugiyono, Prof. Dr., (2012). Metode penelitian Kuantitatif, Kualitatif, dan R\&D. Bandung: Alfabeta.

Suharsaputra, Uhar (2012). Metode Penelitian(Kuantitatif, Kualitatif, dan Tindakan), Bandung: Refika Aditama

Suyanto, dkk. (2013). Menjadi Guru Profesional (Strategi Meningkatkan Kualifikasi dan Kualitas Guru di Era Global). Jakarta: Erlangga

Wiyani, Ardy, Novan. 2012. Manajemen Pendidikan Karakter (Konsep dan Implementasinya di Sekolah). Yogyakarta: PT Pustaka Insan Madani

Zubaedi. (2013). Desain Pendidikan Karakter (Konsepsi dan Aplikasinya dalam Lembaga Pendidikan) cetakan 3. Jakarta : Kencana.

Zulkifli, L. (2006). Psikologi Perkembangan. Bandung: PT. Remaja Rosdakarya 